\title{
Detection of minimal residual disease in lung cancer
}

\author{
Josef Chudaceka, Tomas Bohanes a, Jiri Klein ${ }^{b}$, Andrea Benedikovac, Josef Srovnalc, Marek Szkorupac, Pavel Skalickya, \\ Jozef Skardad ${ }^{\mathrm{d}}$, Marian Hajduch', Cestmir Neoral ${ }^{\mathrm{a}}$
}

Background. Even after successful radical treatment of lung cancer, patients in stages I and II of the TNM system very frequently suffer recurrence, which end lethally. Detection of subclinical residual disease after surgery is thus one of the most important emerging diagnostic methods.

Minimal residual disease (MRD) is defined as the presence of isolated tumor cells or circulating cells in a patient after curative primary tumor removal and at the same time, no clinical signs of cancer. Conventional methods cannot detect minimal residual disease and hence there is a need for detection using new molecular biological methods.

Methods. We searched the PubMed database for original and review articles on minimal residual disease in lung cancer. Search words were "lung cancer", "minimal residual disease" and "detection of minimal residual disease". The publications we found were compared with the results of our own studies on the detection of minimal residual disease in lung cancer and the personal experiences are described. Examination of blood samples from 98 healthy volunteers and bone marrow from 12 patients with non inflammatory and non tumour illness, were used to determine cut-off values for specific markers in the compartments. Subsequently, expression of selected markers in tumor tissue was analysed in a pilot sample of 50 patients with lung cancer and the presence of MRD was measured as expression of values of the tested markers correlated with clinico-pathological characteristics.

Conclusions. Recent studies on other malignancies apart from lung cancer have shown the importance of MRD detection in the determination of disease progression and prognosis. The methods of MRD diagnostics are based on detection of specific tumor markers. Of these, the most specific for lung cancer, appears to be the LunX protein. The best method for determining MRD is probably RT-PCR. Further studies should expand knowledge in this area: to refine understanding of the importance of tumor markers for prognosis, as well as to confirm the significance of these findings in clinical practice.

Key words: lung cancer, minimal residual disease, detection of minimal residual disease

Received: October 17, 2012; Accepted with revision: February 28, 2013; Available online: April 2, 2013

http://dx.doi.org/10.5507/bp.2013.019

${ }^{a}$ Department of Surgery I, University Hospital Olomouc and Faculty of Medicine and Dentistry, Palacky University Olomouc, Czech Republic ${ }^{b}$ Department of Surgery, The District Hospital of Tomas Bata, Zlin

'Laboratory of Experimental Medicine, Institute of Molecular and Translational Medicine, Faculty of Medicine and Dentistry, Palacky University Olomouc and University Hospital Olomouc

dInstitute of Pathology, Faculty of Medicine and Dentistry, Palacky University Olomouc and University Hospital Olomouc

Corresponding author: Tomas Bohanes, e-mail: tomas.bohanes@fnol.cz

\section{INTRODUCTION}

Lung cancer is a common cancer in the human population with an increasing incidence worldwide. In 2008, there were globally 1.61 million new cases and a resulting 1.38 million deaths (globocan.iarc.fr). In the Czech Republic, lung cancer ranks fourth after prostate, breast and colorectal tumors. In 2008 there were a total of 6527 cases of lung cancer ( 4693 or 91.8 cases per 100000 men and 1,834 cases or 34.5 cases per 100000 women) (www.uzis.cz). Compared to prostate, breast and colorectal cancer, however, lung cancer takes precedes in terms of mortality as one of the most lethal of cancers. Prognosis in the case of late-diagnosed or untreatable patients is a median survival of 17 months from diagnosis. Current treatment is usually multimodal but the only curative method remains surgical lung resection followed by radical lymphadenectomy. Curative surgery, however, is only possible in approximately $20 \%$ of patients ${ }^{1}$.
The most important factors in disease prognosis remain histological tumour type (e.g.small cell v non-small) and TNM classification. However, even in stage I, only $57-78 \%$ of patients survive 5 years, the 5-year survival in stage II is between $39-66 \%$, in stage IIIA it is between 23 $33 \%$ and in stage IV, 5-year survival is rare. Relapses occur despite adequate treatment in about $70 \%$ of patients in stages I and II. In $80 \%$, the recurrence is due to systemic disease, which despite intensive treatment is the cause of death. It follows that in patients in the early stages, there is subclinical systemic disease which, although we are unable to detect it using conventional methods, is the origin of the disease recurrence ${ }^{2}$.

Current conventional examination methods (light microscopy, immunohistochemistry, flow cytometry, etc.) cannot usually reveal early dissemination and especially circulating and disseminated tumor cells, which become the precursors of distant metastases. Only with the use of new molecular biological methods can these individual 
tumor cells and/or their clusters be detected in the body and thus enable determination of the systemic extent of the disease, monitoring of treatment and detection of early relapse.

Minimal residual disease (MRD) is defined as the presence of such isolated or circulating tumor cells in a patient in whom there has been curative primary tumor removal and at the same period no clinical signs of cancer. Tumor cells can be detected in the blood (Circulating tumor cells, CTS) in the bone marrow (disseminated tumor cells, DTS), in the lymphatic system, in the pleural effusion, or fluid in the abdominal cavity ${ }^{3}$. Commonly used imaging, biochemical, cytogenetic and immunological methods are able to detect 1 cancer cell among 10 to 100000 non tumor cells. The introduction of new molecular biological methods based on the principle of polymerase chain reaction (PCR) allows us detect one cancer cell in 10 million non tumour cells ${ }^{4}$. This method was first used in hematooncology, where well-described genetic changes and highly specific and sensitive markers of tumor cells were discovered ${ }^{5,6}$.

For solid tumors, the situation is seriously hampered by lack of known sufficiently sensitive and specific tumor markers of circulating tumor cells due to the high degree of genetic instability and tumor heterogeneity. The principle of detecting residual disease in epithelial tumors is the detection of epithelial cancer cell markers in mesenchymal areas, i.e. in an atypical environment for them. By taking samples from patients before and after surgery it is possible from decrease or increase in the gene expression of tumor markers, to monitor the development of the cancer and treatment effect. In the case of increase in monitored markers, it is possible to detect the recurrence of cancer before clinical symptoms develop. This finding is important in treatment strategies and disease prognosis ${ }^{7}$. At present, a number of studies are in progress on the prognostic significance of MRD. However, despite ever new findings suggesting the potential clinical value of determining MRD, the relevance of residual populations of tumor cells in mesenchymal compartments after radical surgery is not sufficiently elucidated. This is due to the heterogeneity of the methods used and in the tumour samples, a lack of a statistically significant group of patients whose MRD positivity or negativity was correlated with clinically defined macroscopic status.

\section{METHODS}

\section{Methods for MRD detection}

To determine MRD several methods with different sensitivity, specificity, cost and technical complexity can be used.

First immunohistochemistry: reactions of monoclonal antibodies to specific antigens of tumor cells.

Second flow cytometry: determination of quantity of surface and intracellular antigens using monoclonal antibodies conjugated with fluorescent dye passing through a measuring chamber, where it is linked to fluorochrome ex- citation and emitted radiation is detected by a photomultipliers. The resulting signal is processed by a computer.

Third polymerase chain reaction - PCR: detection of selected DNA sequences through its amplification using sequence-specific oligonucleotides and DNA polymerase.

Fourth, transcriptase polymerase chain reaction in real time - RT-PCR: the most sensitive method based on the principle of reverse - transcriptase polymerase chain reaction in real time, using which it is possible to detect a single cancer cell among 10 million non tumour cells. RTPCR is the study of gene expression, where the screened character of epithelial tumor cells is the information messenger RNA (mRNA). It has been repeatedly demonstrated in numerous studies that RT-PCR is the most accurate and most sensitive method for the determination of circulating tumor cells in colorectal cancer, breast cancer, renal cell carcinoma ${ }^{8-10}$ and pancreatic cancer ${ }^{11,12}$.

\section{Tumor markers}

Individual markers used to determine minimal residual disease, differ in their specificity and sensitivity. Among the most widely used tumor markers is the carcinoembryonic antigen (CEA). This is a cell surface glycoprotein, whose expression is elevated in $95 \%$ of tumors of the gastrointestinal tract, $70 \%$ of non-small cell lung cancers (NSCLC) and $50 \%$ of breast cancers ${ }^{13}$. Another suitable marker is the receptor for the epidermal growth factor-1 (EGFR-1), belonging to the HER group. Differences in the expression of various growth factor HER groups in various types of cancers can be used as diagnostic and prognostic factors in determining MRD. It is increasingly being shown that EGFR1 expression is raised in $70 \%$ of breast, lung and intestinal cancers ${ }^{14}$. The receptor for the hepatocyte growth factor (c-MET), which after binding to the membrane receptor, stimulates the hepatocyte growth factor, has a number of other important functions in the development and regeneration of tissues. It also participates in oncogenesis and the progression of cancers. Cytokeratin (CK 19) belonging to the group of proteins of the epithelial cell cytoskeleton, is also used as a marker for MRD in colorectal and breast cancer ${ }^{15}$.

\section{Detection of minimal residual disease in lung cancer}

Progress in the diagnosis of lung cancer is greatly limited by the lack of diagnostic markers as mentioned. However, there has been some recent progress. After failure in using existing markers, in 2001, Japanese researchers identified a promising new lung-specific protein, LunX. Its gene was localized to chromosome 20p11 1 - q12 and identified using the RT-PCR method $^{16}$. In that study, 104 lymph nodes in 20 patients with NSCLC were examined. LunX mRNA expression was identified in $16(80 \%)$ of the 20 histologically positive nodes and $21(25 \%)$ of 84 histologically negative lymph nodes. The authors concluded that the RT-PCR test for the presence of LunX is a suitable diagnostic method for the detection of metastatic NSCLC.

In 2008, Cheng developed a study to evaluate in detail the importance of tumor markers and assess their diagnostic significance in NSCLC. Again they used RT- 
PCR to detect mRNA for LunX, CK19 and CEA in peripheral blood and pleural fluid. They compared a group of patients with NSCLC with a group of patients with other epithelial cancers (breast cancer and oesophagus). Another group consisted of patients with benign lung disease and in the last group were only healthy individuals. In peripheral blood, increased levels of LunX mRNA were found in 33 out of 44 patients with NSCLC. In patients with epithelial carcinomas $(0 / 28)$, in benign lung disease $(0 / 10)$ and in healthy volunteers $(0 / 15)$ no elevated LunX mRNA was detected. All other genetic markers were positive not only in patients with NSCLC, but also in other groups. The rate of positivity of LunX mRNA in peripheral blood was associated with cancer progression. Further, LunX mRNA was detected in $92.2 \%$ (13/14) of patients in samples of malignant pleural effusion, but was absent in benign effusions. The examined patients showed reduced LunX mRNA expression in peripheral blood after initiation of treatment. The authors concluded that LunX mRNA was the most specific gene marker for lung cancer of the tumor markers used in this study ${ }^{17}$.

The aim of Japanese authors led by Fumihury Tanaka in 2009 was to determine the prognostic significance of CTCs in the peripheral blood of patients with lung cancer, with non tumour disease and in patients with distant metastases ${ }^{18}$. They demonstrated a greater number of CTCs in patients with lung cancer, but this difference was not statistically significant. For patients with disease progression,and in particular with the development of distant metastases there was a statistically significant increase in number of CTCs (sensitivity $71 \%$, specificity $83 \%$ ) detected by antibodies against epithelial adhesion molecule (EpCAM).

C-Met receptor and its ligand, hepatocyte growth factor is involved in tumor invasiveness and metastasis formation. Overexpression of c-Met was detected in lung cancer, but so far it has not been assessed as level of c-Met in peripheral blood. Monitoring of c-Met might be useful for selecting patients for adjuvant cancer therapy ${ }^{19,20}$. It has been repeatedly demonstrated in lung cancer, that c-Met is involved in angiogenesis, growth and invasion ${ }^{21}$. The first study to focus on the presence of c-Met in peripheral blood and its prognostic significance in patients with NSCLC, was done by Chinese researchers in 2005. c-Met RNA was investigated in tumor tissue and peripheral blood of patients with NSCLC using RT-PCR and the results were compared with immunohistochemical methods. The study found a potential role for c-Met as a prognostic factor in NSCLC. The results showed that c-Met intumor tissue is associated with number of c-Met in circulating blood. Increased levels of circulating c-Met significantly correlated with lymph node involvement, which means that in NSCLC patients with higher levels of c-Met there was more disease advancement. C-Met accurately predicts risk of recurrence and metastasis. Overexpression of c-Met was found in $75.5 \%$ of cases using RT-PCR in comparison with $60 \%$ using immunohistochemical methods. RT-PCR has a high detection rate and low variability in assessing gene expression. This is consistent with the results of other studies showing that
RT-PCR is more sensitive than immunohistochemistry ${ }^{22}$. The above study also showed that the expression of c-Met in peripheral blood signals a high risk of recurrence and is an independent negative prognostic factor in patients with NSCLC ( ref. $^{23}$ ).

Jiam Ming et al tracked the number of circulating tumor cells in patients with NSCLC in the perioperative period using RT-PCR. They chose as markers CK19 and CEA, which were examined in 69 peripheral blood samples. The group included 23 patients with NSCLC who had undergone radical surgery. Blood samples were taken before, during and after the surgery. Before surgery, patients were randomly divided into 2 groups. One group underwent ligation of the pulmonary vein first and in the second, ligation was performed first on the pulmonary artery. The control group included ten patients with benign disease who underwent surgical resection. The results suggest that assessment of systemic involvement in patients with NSCLC is preferable using both CEA and CK19. Cells expressing CK19 were already circulating during the operation, and cells that expressed CEA were frequently disseminated only in the postoperative period. Surgical manipulation may lead to the dissemination of tumor cells into the blood circulation but this could be prevented by ligation of the pulmonary vein before pulmonary artery ligation $^{24}$.

In 2002, Masato et al focused on small-cell lung cancer (SCLC), which tends to hematogeníc rapid progression. To detect the microscopic spread of tumor they examined specific genes in peripheral blood and bone marrow. Markers used were trans-gastrin-realeasing peptide (preproGRP), Neuromedin B receptor, gastrin releasing peptide receptor. The results were again analyzed by RTPCR. All three tumor markers were detected in the bone marrow, often with distant metastases and in SCLC using RT-PCR in bone marrow they indicate a poor prognosis ${ }^{19}$.

\section{Our experience}

The Laboratory of Experimental Medicine, Institute of Molecular and Translational Medicine, Palacky University Olomouc and First Department of Surgery, University Hospital in Olomouc have the most extensive experience in the Czech Republic in the determination of minimal residual disease in breast, colorectal and pancreatic cancer. In recent years, research has focused on the determination of minimal residual disease in lung cancer.

For the detection of MRD, patients with NSCLC were examined using RT-PCR to detect RNA carcinoembryonic antigen (CEA), the receptor for epidermal growth factor receptor (EGFR), lung-specific X protein (LunX) and the receptor for hepatocyte growth factor (c-Met) as markers of tumor cells.

Based on examination of blood samples from 98 healthy volunteers and bone marrow from 12 patients with non inflammatory and non tumour illness, statistical analyses were used to determine cut-off values for each marker in the compartment (Table 1). Further, expression of selected markers in tumor tissue was analysed. The results showed that LunX is highly expressed specifically in tumors of lung origin as well as CEA and EGFR. c-Met 
lacks specificity. After examination, the presence of MRD in a pilot sample of 50 patients with lung cancer was measured as expression of values of tested markers correlated with clinico-pathological characteristics (Table 2). The results of the analysis showed that LunX is a good candidate for the detection of MRD in patients with lung cancer. Determination of MRD in lung cancer is a promising prognostic indicator. Its true clinical significance however remains and the results call for another study ${ }^{25}$.

\section{DISCUSSION}

Hematologists have the greatest experience in monitoring minimal residual disease as the hallmark of successfully treated hemoblastosis is to achieve complete remission $^{5,6}$. The issue is whether remission assessed only by classical methods (microscopy, radiodiagnostics), can be called a complete clinical remission (CCR): when relapse can occur due to the inability of routine methods to capture residual tumor cells. Molecular-genetic methods that achieve a sensitivity of 10-5 to 10-7 cells are still frequently used for the detection of residual tumor disease. If we determine remission by these methods, we call it a complete molecular remission (MCR), which for hematoblastosis is a positive prognostic factor ${ }^{5}$.

Solid tumors too are shown to have their "leukemic" phase $^{26}$. Metastatic dissemination, ceteri paribus, is conditioned by release of tumor cells into the circulation. The models showed that 1 gram of tumor tissue can release into the circulation up to one million tumor cells per day.

Table 1. Cut-off values for markers in the specified compartments.

\begin{tabular}{ccc} 
& Periferal blood & Bone marrow \\
\hline CEA & $200 \mathrm{cop} / \mu \mathrm{g}$ RNA & $350 \mathrm{cop} / \mu \mathrm{g}$ RNA \\
c-met & $8500 \mathrm{cop} / \mu \mathrm{g}$ RNA & $11500 \mathrm{cop} / \mu \mathrm{g}$ RNA \\
EGFR & $250 \mathrm{cop} / \mu \mathrm{g}$ RNA & $30000 \mathrm{cop} / \mu \mathrm{g}$ RNA \\
LUNX & $30 \mathrm{cop} / \mu \mathrm{g}$ RNA & $550 \mathrm{cop} / \mu \mathrm{g}$ RNA \\
\hline
\end{tabular}

The values were obtained by analyse of the examination of blood samples from 98 healthy volunteers and bone marrow from 12 patients with an inflammatory disease.
Unlike hematoblastosis, the tumor cells in the circulation, are exposed to hormone and cellular immune mechanisms. They have to withstand adverse conditions. The processes allowing tumor cells to remain in circulation and go on to establish metastases are being recognised very slowly. Not every cancer cell is able to enter the circulation and create a metastasis. Of a number of circulating apoptotic cells, some are dormant; more are incapable of protein synthesis, cell proliferation and induction of angiogenesis ${ }^{27}$. Most are destroyed by the immune system. For this reason, detectiing circulating tumor cells using highly sensitive molecular-genetic methods does not mean automatic relapse or persistence of the tumor. In connection with sentinel nodes in breast cancer, Weaver postulated that polymerase chain reaction used for tumor cell markers is too sensitive and identifies many PCR positive cases and that this number far exceeds the empirical rate of recurrence ${ }^{28}$. It is therefore clear that only further studies will be able to answer the question of the real clinical significance of detecting minimal residual disease for prognosis and for tailoring the treatment strategy.

Several studies ${ }^{16-25}$, published in this area with a focus on lung cancer, have provided knowledge of the clinical significance of tumor markers for the detection of MRD. Of these the most specific marker appears to be Lunx protein ${ }^{16,17,25}$, although some other markers appear to be applicable for MRD detection in lung cancer, especially CEA (ref. ${ }^{17,24,25}$ ). For others (c-Met), the results are inconsistent and controversial ${ }^{20-23,25}$.

One interesting impact study on ascertaining MRD in lung cancer is about the effect of tumor manipulation, the lung and pulmonary vascular ligation sequence and consequent risk of inducing tumor cell dissemination ${ }^{24}$. In clinical practice, thoracic surgery is still predominantly a technicist approach, requiring primarily ligation of arteries first and then veins during pulmonary resection, as there is greater concern for bleeding in lung parenchyma in the case of the opposite procedure. However, the method used does not logically prevent the spread of cancer cells released in the direction of the blood flow in the pulmonary veins of the left atrium of the heart and into the systemic circulation. This fact should be the basis for discussing changes in procedure for resection.

Table 2. Expression of tested markers.

\begin{tabular}{|c|c|c|c|c|c|c|c|c|}
\hline \multirow{2}{*}{$\begin{array}{c}\begin{array}{c}\text { Clinical } \\
\text { stage }\end{array} \\
\text { I }\end{array}$} & \multicolumn{2}{|c|}{$\begin{array}{c}\text { Positivity of CEA } \\
\text { in bone marrow } \\
\% \text { (positive/total) }\end{array}$} & \multicolumn{2}{|c|}{$\begin{array}{l}\text { Positivity of c-met } \\
\text { in systemic blood } \\
\% \text { (positive/total) }\end{array}$} & \multicolumn{2}{|c|}{$\begin{array}{l}\text { Positivity of LUNX } \\
\text { in lung vein blood } \\
\% \text { (positive/total) }\end{array}$} & \multicolumn{2}{|c|}{$\begin{array}{l}\text { Total positivity } \\
\text { of LUNX } \\
\% \text { (positive/total) }\end{array}$} \\
\hline & 41.4 & $(12 / 29)$ & 6.9 & $(2 / 29)$ & 3.6 & $(1 / 28)$ & 21.4 & $(6 / 28)$ \\
\hline II & 63.6 & $(7 / 11)$ & 9.1 & $(1 / 11)$ & 30.0 & $(3 / 10)$ & 2.0 & $(2 / 9)$ \\
\hline III & 77.8 & $(7 / 9)$ & 25.0 & $(2 / 8)$ & 28.6 & $(2 / 7)$ & 3.0 & $(3 / 7)$ \\
\hline
\end{tabular}

The results are correlated with clinico-pathological characteristics. 


\section{CONCLUSION}

As with other malignancies, where recent studies demonstrate the importance of MRD detection in the determination of disease progression and prognosis, in lung cancer the contribution of MRD determination is based on detection of specific tumor markers as well. Of these, the most specific, based on several studies appears to be the LunX protein, although several studies have shown the benefits of other markers. Further studies should expand knowledge in this area: to determine the significance of tumor markers in prognosis, for confirming the findings in the clinical treatment of patients and for identifying their real benefits.

\section{ACKNOWLEDGEMENTS}

This study was supported by grants IGA NT14406, IGA UP LF_2013_015, MPO TIP FR-TI1/525, CZ.1.05/2.1.00/01.0030 and CZ.1.07/2.3.00/30.0004.

\section{REFERENCES}

1. Klein J. Chirurgie karcinomu plic. Praha: Grada publishing; 2006.

2. Depierre A, Milleron B, Moro-Sibilot D, Chevret S, Quoix E, Lebeau B, Braun D, Breton JL, Lemarié E, Gouva S, Paillot N, Bréchot JM, Janicot H, Lebas FX, Terrioux P, Clavier J, Foucher P, Monchâtre M, Coëtmeur D, Level MC, Leclerc P, Blanchon F, Rodier JM, Thiberville L, Villeneuve A, Westeel V, Chastang C; French Thoracic Cooperative Group. French Thoracis Cooperative Group. Peroperative chemotherapy followed by surgery compared with primary surgery in resectable stage (except T1NO), II, and IIla non-small cell lung cancer. J Clin Oncol 2002;20:247-53.

3. Pantel K, Cote RJ, Fodstad O. Detection nad clinical importace of micrometastatic disease. J Natl Cancer Inst 1999;91:1113-24.

4. Amutan M, Batey D. Real-time quantification of genomic DNA using DyNAzyme II DNA polymerase and SYBR Green I Dye [online]. [cited 2012 Jan 6]. Available from: http://wwww.bio-medicine.org/biology-technology/Real-Time-Quantification-of-Genomic-DNA-UsingDyNAzyme-II-DNA-Polymerase-and-SYBR-Green-I-Dye-1147-1/

5. Hagenbeek A. Minimal residual disease in leukemia: state of the art 1991. Leukemia 1992;6,12-6.

6. Černý J, Trněný $M$, Klener $P$. Význam minimálni reziduální nemoci a metody jejího stanovení u pacientů s některými hematologickymi malignitami. Klin Onkol 2003;16:41-8.

7. Srovnal J.: Minimální reziduální choroba u solidních nádorů. Olomouc 2009. Disertační práce. LF UP Olomouc.

8. Mori M, Mimori K, Inoue H, Barnard GF, Tsuji K, Nanbara S, Ueo H, Akiyoshi T. Detection of cancer micrometastases in lymph nodes by reverse transcriptasepolymerase chain reaction. Cancer Res 1995;55:3417-20.

9. Noguchi $\mathrm{S}$, Aihara T, Motomura K, Inaji H, Imaoka S, Koyama H. Detection of breast cancer micrometastases in axillary lymph nodes by means of reverse transcriptase-polymerase chain reaction: comparison between MUC1 mRNA and keratin 19 mRNA amplification. Am J Pathol 1996;148:649-56.

10. Pantel K, Von Knebel Doeberitz M. Detection and clinical relevance of micrometastatic cancer cells. Curr Opin Oncol 2000;12:95-101.

11. Klos D., Loveček M, Skalický P, Srovnal J., Kesselová M., Radová L., Hajdúch M., Neoral Č., Havlík R.. Minimální reziduální choroba u karcinomu pankreatu-naše prvotní zkušenosti. Rozhl Chir 2010;89(2):135-9.
12. Klos $D$, Loveček $M$, Srovnal J. Možnosti využití stanovení minimální reziduální choroby u adenokarcinomu pankreatu pomocí metodiky real-time RT-PCR - pilotní studie. Cas Lek Cesk. 2010;149(2):69-73.

13. Aquino A, Formica V, Prete SP, Correale PP, Massara MC, Turriziani $M$, De Vecchis L, Bonmassar E. Drug-induced increase of carcinoembryonic antigen expression in cancer cells. Pharmacological Res. 2004;49(5):383-96.

14. De Luca A, Pignata S, Casamassimi A, D'Antonio A, Gridelli C, Rossi A, Cremona F, Parisi V, De Matteis A, Normanno N. Detection of circulating tumor cells in carcinoma patients by a novel epidermal growth factor receptor reverse transcription-PCR assay. Clin Cancer Res 2000;6,1439-44.

15. Ignatiadis M, Kallergi G, Ntoulia M, Perraki M, Apostolaki S, Kafousi M, Chlouverakis G, Stathopoulos E, Lianidou E, Georgoulias V, Mavroudis D. Prognostic values of the molecular detection of circulating tumor cells using a multimarker reverse transcription-PCR assai for cytokeratin 19, mammaglobin A, and HER2 in early breast cancer. Clin Cancer Res 2008;9,2593-9.

16. Iwao K, Watanabe T, Fujiwara Y, Takami K, Kodama K, Higashiyama M, Yokouchi H, Ozaki K, Monden M, Tanigami A. Isolation of a novel human lung-specific gene, LUNX, a potentional molecular marker for detection of micrometastasis in non-small-cell lung cancer. Int J Cancer 2001;91,433-37.

17. Cheng M, Chen Y, Yu X, Tian Z, Wei H. Diagnostic utility of LunX mRNA in peripheral blood and pleural fluid in patients with primary non-small cell lung cancer. BMC Cancer 2008;8, 156-67.

18. Tanaka F, Yoneda K, Kondo N, Hashimoto M, Takuwa T, Matsumoto S, Okumura Y, Rahman S, Tsubota N, Tsujimura T, Kuribayashi K, Fukuoka K, Nakano T, Hasegawa S. Circulating Tumor cell as a Diagnostic Marker in Primary Lung Cancer. Clin Cancer Res 2009;15,6980-6.

19. Shingyoji M, Takiguchi $Y$, Watanabe R, Hiroshima K, Motoori K, Kurosu K, Kasahara Y, Tanabe N, Tatsumi K, Kuriyama T. Detection of tumor specific gene expresion in bone marrow and peripheral blood from patients with small cell lung carcinoma. Cancer 2003;4,1057-67.

20. Schuster R, Max N, Mann B, Heufelder K, Thilo F, Gröne J, Rokos F, Buhr HJ, Thiel E, Keilholz U. Quantitative real-time RT-PCR for detection of disseminated tumor cells in peripheral blood of patients with colorectal cancer using different mRNA markers. Int J Cancer 2004;108:219-27.

21. van der Voort R, Taher TE, Derksen PW, Spaargaren M, van der Neut R, Pals ST. The hepatocyte growth factor/Met pathway in development, tumorigenesis and B-cell differentiation. Adv Cancer Res 2000;79:3990

22. Thomasson M, Hedman H, Guo D, Ljungberg B, Henriksson R. LRIG1 and epidermal growth factor receptor in renal cell carcinoma: a quantitative RT-PCR and immunohistochemical analysis. Br J Cancer 2003; 89:1285-9.

23. Cheng TL, Chang MY, Huang SY, Sheu CC, Kao EL, Cheng YJ, Chong IW. Over expression of circulating c-Met messenger RNA is significantly correlated with nodal stage and early recurence in non-small cell lung cancer. Chest 2005;128:1453-60.

24. Ge MJ, Shi D, Wu QC, Wang M, Li LB. Observation of circulating tumour cells in patients with non-small cell lung cancer by real-time fluorescent quantitaive reverse transriptase-polymerase chain reaction in peroperative period. J Cancer Res Clin Oncol 2006;132:24856.

25. Benedíková A, Srovnal J, Szkorupa M, et al. Biomarkery detekce minimální systemové diseminace u nemocných s karcinomem plic. Rozhl Chir 2012;91:217-23.

26. Mocellin S, Hoon D, Ambrosi A, Nitti D, Rossi CR. Circulating tumor cells: the leukemic phase of solid cancers. Trends in Mol Med 2006,12:130-9.

27. Rosenberg $R$, Nekarda $H$, Thorban S, Siewert JR. Minimal residual disease in gastrointestinal tumors: tumor cell detection in bone marrow, blood and lymph nodes. Acta Med Austriaca 2002;29:42-53.

28. Weaver DL. Sentinel lymph node biopsy in breast cencer: creating controversy and defining new standards. Adv Anat Pathol 2001;8:6573. 